\title{
NOTES
}

\section{THE NEW YORK MEDICAL EXPERT PROJECT: AN EXPERIMENT IN SECURING IMPARTIAL TESTIMONY}

INCREASING specialization of medical knowledge as well as the current flood of personal injury suits have led courts to rely heavily on the testimony of physicians. ${ }^{1}$ But when experts summoned by the parties ${ }^{2}$ present videly differing opinions, the judge and the jury are often unable to choose between them intelligently. ${ }^{3}$ Judges, lawyers, and doctors have consistently reiterated the need for non-partisan testimony. ${ }^{4}$

Members of the legal and medical professions in New York City have recently put into operation the Medical Expert Testimony Project. Supported for an experimental period by funds from private foundations," the Project was instituted in the Supreme Court of New York County by order of the Appellate Division on December 1, 1952. ${ }^{\circ}$ The Project establishes a perma-

1. Mock, MIedical Testimony, 1 Axr. J. MIED. JurIs. 119 (1938). For more extensive treatment, see 2 Wignone, Evidence $\$ 563$ (3d ed. 1940) ; Symposium, 2 LAW Asd Co:iTEATr. PrOB. 401-524 (1935).

2. Since the early English practice of retaining experts as both witnesses and judges in questions involving knowledge of a particular trade was abandoned, slilled practitioners have been summoned to testify by the adverse parties, with the judge or jury designated as the ultimate finder of fact. This method gives rise to the so-called "battle of esperts." See Model Expert Testimony Act Commissioners' Prefatory Note, 9 U.L.A. 427 (1951) ; Rosenthal, The Development of the Use of Expert Testimony, 2 LAw Aro Co:iTEATP. PRos. 403-18 (1935).

3. The current system requires laymen to resolve discrepancies among experts. As a result, irresponsible oversimplifications by a brash or unserupulous vitness are likely to carry more weight than the guarded statements of the careful specialist.

Divergence between physicians' diagnoses may be the result of honest differences of opinion, or of unscrupulous maneuvering. "That medical opinion can be bought with a price, no one can satisfactorily deny, and this problem has been for some years, and is at the present time, giving the thinking men of the medical profession grave concern, both locally and nationally." Fouts, The Medical Expert II imess, 19 Nen L. BuLn 213 (1940).

4. See authorities collected in 2 Wigmone, Evmence 645 n.2 (3d ed. 1940).

Scrupulous physicians are often made uncomfortable by the partisan quality of their appearance, the scathing cross-examination, and the contentious atmosphere that the average personal injury case involves. "Professional men of honorable instincts and high scientific standards began to look upon the witness box as a golgotha, and to disclaim all respect for the law's methods of investigation." 2 Wrgsore, Evimence 645 (3d ed. 1940).

"The remedy can only come when the state shall provide that the courts, and not the litigants, shall call a disinterested body or board of experts who shall reviev the whole situation and then give their opinion, with their reasons therefor, to the court and jury, regardless of the consequences to either litigant." In re Dolbeer's Estate, 149 Cal. 227, 243, 86 Pac. 695, 702 (1906).

5. The Alfred P. Sloan Foundation and the Ford Motor Company Fund.

6. Special Rule, Supreme Court, New York County, dated November 24, 1952. 
nent panel of impartial physicians to act in personal injury cases. The panel, consisting of experts in a number of medical fields, ${ }^{7}$ is designated by local medical organizations. ${ }^{8}$ The Project is administered through the Medical Report Office, which is in charge of a deputy clerk of the Supreme Court. The judge at the pre-trial conference may on his own motion ${ }^{0}$ order an examination of the claimant by a panel expert and a report thereon. When combined with the strict requirements for pre-trial screening in New York County, ${ }^{10}$ the Project introduces impartial expert opinion into the litigation at an early stage. The sponsors hope the Project will provide impetus toward settlement that will alleviate the judicial log jam flowing from the voluminous personal injury litigation in New York County. ${ }^{11}$ If no settlement is reached, the case proceeds to trial, perhaps with its medical issues narrowed. And either party or the trial judge may call the examining physician as a witness, subject to questioning or rebuttal by any party. ${ }^{12}$

Earlier efforts to secure non-partisan medical testimony achieved only limited acceptance. The Model Expert Testimony Act, ${ }^{13}$ while favorably commented upon, ${ }^{14}$ has thus far been adopted only in South Dakota. ${ }^{16}$ The Act provides that at any time in any action, when issues arise upon which the court deems expert evidence desirable, the judge may on his own motion or on motion of the parties appoint one to three experts on each issue, to

7. The panel includes experts in general surgery, plastic surgery, ophthalmology, cardiovascular diseases, dermatology, tuberculosis, internal medicine, neurosurgery, neurology, psychiatry, neuropsychiatry, roentgenology, orthopedics, otolaryngology, gynecology, and urology.

8. The New York Academy of Medicine and the New York County Medical Socicty.

9. The judge is not required to preface his action with a hearing at which the advisability of consulting impartial experts might be debated by the parties. In this respect the New York Project differs from the Model Code of Evidence and FEv. R. Civ. P. 35. See note 18 infra, and text at notes 19-25 infra.

10. All cases placed on the trial terms in the Supreme Court of New York County must first pass through the pre-trial parts, at which time a settlement is sought. Refusal to appear for the pre-trial hearing may result in dismissal of the action. NEw Yonk County Supreme Court Rules, Trual Terms' Rule IX (Cahill-Parsons Supp. 1953).

11. "The Supreme Court tort jury calendar, meaning principally the line-up of negligence cases awaiting trial, is now close to four years behind- 46 months to be exact." David W. Peck, Presiding Justice, New York Supreme Court, Appellate Division, First Department, addressing members of the bar and executives of casualty insurance companies, Jan. 14, 1952. And see note 39 infra.

12. Doubt has been expressed as to the effectiveness of the rights of cross-cxamination and rebuttal under the Project, since juries tend to endow the court-appointed doctor with "special sanctity." Communication to the Yale LAw Journal from Isidore Halpern, Esq., New York trial attorney, dated April 6, 1954, in Yale Law Library.

13. Model Expert Testimony Act, 9 U.L.A. 427 (1951). The Model Act was drafted by the Commissioners on Uniform Lays in 1937.

14. Challener, The Expert Medical Witness and the Model Expert Testimony Act, 22 PENN. B.A.Q. 304 (1951).

15. The Act was adopted by rule of the South Dakota Supreme Court, Order No. 5, 1942, and was subsequently made statutory. S.D. CoDE tit. 36, c. 36.01 (Supp. 1952). 
testify at the trial. ${ }^{16}$ The experts may be called at the trial by the court or by either party, and their testimony is subject to cross-examination or rebuttal. ${ }^{17}$ The provisions for expert testimony in the American Law Institute's Model Code of Evidence are essentially similar to the Model Act. ${ }^{18}$ However, without adequate administrative facilities and judicial procedures insuring their use, the Model Act and the Model Code cannot attain a full measure of practical effectiveness.

A solution which has received more application than the Model Act is embodied in Rule 35 of the Federal Rules of Civil Procedure. ${ }^{19}$ Three states have written the Rule into their own procedure verbatim; $;^{20}$ six others have provisions closely based upon it. ${ }^{21}$ Rule 35 enables a judge to order a person to submit to a mental or physical examination by a physician "in an action in which the mental or physical condition of a party is in controversy." 2 Furthermore, the order may be made only after a hearing. ${ }^{23}$ IVhile the Rule does not specify, the court apparently need not wait for a motion from the parties before appointing experts, but may do so on its own motion." And

16. Miodet Expert Testrusony Act $\$ 1$.

17. Id.\$ $\mathrm{S}$.

18. MODEL CODE of Evidence Rules 403-10 (1942).

The Irodel Code calls for more formal preliminaries than does the Model Act. Rule 403 of the Code insists upon a show-cause hearing before expert witnesses may be appointed. The drafters commented: "It seems only fair to give the parties an opportunity to be heard on the question whether expert evidence is needed or desired as well as to present arguments for or against the selection of specified experts." Mors CODE of EvIDENCE 203 (1942). The Model Act simply requires reasonable notice to the parties; no hearing is necessary. MODEL Expert Testmony ACr $\$ \$ 1,2$, 4. Similarly, Rule 405 of the Model Code, dealing with the examination and report of the experts, contains far more elaborate requirements for hearings than do the Model Act's counterparts, \$\$ 5-7.

19. FED. R. CIV. P. 35.

20. ArIz. R. Civ. P. 35 (1940) ; DeL. Super. CT. Rule 35 (1948); N.M. R. CIv. P. 35 (1942).

21. Colo. R. CTv. P. 35 (1941); Fla Coxraron L.R. 28 (1950); Iowa R. Cw. P. 132, 133 (1951); Mo. Rev. Stat. $\$ 510.040$ (1949); N.J. Cт. Rules 4:25-1, 2 (1953); UTAв R. CIV. P. 35 (1953).

22. FED. R. CIv. P. 35(a). The validity of this Rule was upheld in Sibbach v. Wilson, 312 U.S. 1 (1940). Its application is not limited to personal injury actions. Beach v. Beach, 114 F.2d 479 (D.C. Cir. 1940) (blood test in paternity case); 4 Mroune, Frozan Practice I 35.03 (2d ed. 1950). Contra: Wadlow v. Humberd, 27 F. Supp. 210 (W.D. Mo. 1939) (libel action based on alleged defamatory statements concerning plaintiff's physical and mental condition). A refusal to submit to the order can lead to dismissal of the action. FED. R. CIv. P. 37(b) (2), Klein v. Yellow Cab Co., 7 F.R.D. 169 (N.D. Ohio 1945). The order for examination is interlocutory, and is not appealable. Eowles v. Commercial Casualty Ins. Co., 107 F.2d 169 (4th Cir. 1939).

23. FED. R. CN. P. 35(a).

24. Rule 53 enables a court in which any action is pending to appoint a special master therein. As used in the Rule, "master" includes a referee, an auditor, or on cxamiscr. FED. R. CIV. P. 53 (a). "In actions to be tried by a jury, a reference shall be made only when the issues are complicated; in actions to be tried without a jury, save in matters of account, a reference shall be made only upon a showing that some exceptional con- 
it is clear that the court has the power to appoint an impartial expert if the parties cannot agree as to his identity among themselves. ${ }^{25}$ In such event, the Rule's operation resembles the New York Project; in practice, however, it has generally served as no more than a method of discovery.

A number of states have passed independent statutes or rules, derived neither from the Model Act nor from Federal Rule 35, but attempting to secure a measure of impartiality in expert medical testimony. While the main emphasis to date has been on mental examinations when the issue of insanity is raised in a criminal case, ${ }^{26}$ a few states have extended this principle to civil litigation as well..$^{27}$ Before the institution of the current Project, New York County courts had power to appoint impartial experts in personal injury cases, but only on motion of the parties. ${ }^{28}$ California has a more sweeping statute. ${ }^{29}$ The court may appoint one or more experts to investigate and testify at any stage of a civil or criminal action. In other states there have been holdings that trial judges may appoint impartial experts even in the absence of any enabling legislation. ${ }^{30}$ But prior to the New York experiment,

dition requires it." FED. R. CIV. P. 53(b). While a reference to a master is intencled to be the exception and not the rule, there is apparently no reason why a district court cuuld not appoint an impartial physician as master in a personal injury case when the issues are complicated.

25. Gitto v. "Italia," Societá Americana di Navigazione, 27 F. Supp. 785 (S.D.N.X. 1939).

26. See, e.g., OHio Gen. Code ANN. §13441-4 (Page, 1939). "In any case in which insanity is set up as a defense ... the court shall have power to commit the defendant to a local insane hospital ... and the court may in such case appoint one or more disinterested qualified physicians ... to investigate and examine into the mental condition of the defendant and testify as experts at his trial or other hearing." For a collection of state statutes, see 2 Wigmore, Evidence 649 n.7 (3d ed. 1940). Legislation similar to Ohio's has been held constitutional. People v. Strong, 114 Cal. App. 522, 300 Pac. 84 (1931.) ; State v. Eisenhardt, 185 La. 308, 169 So. 417 (1936) ; State v. Myers, 220 S.C. 309, 67 S.E.2d 506 (1951) ; Jessner v. State, 202 Wis. 184, 231 N.W. 634 (1930). Contra: People v. Dickerson, 164 Mich. 148, 129 N.W. 199 (1910), an opinion criticized in 2 WigMORE, Evidence 649, 652 n.7 (3d ed. 1940).

For a detailed account of the operation of the Colorado statute, see Weihofen, $A n$ Alternative to the Battle of Experts: Hospital Examination of Criminal Defendants before Trial, 2 LAW \& CONTEMr. PROB. 419 (1935).

27. Cal. Code Civ. P. Ann. $\$ 1871$ (Deering, 1953); N.Y. Civ. Prac. Act $\$ 306$; R.I. Gen. Laws c. 537, $\$ \S 20-23$ (1938).

28. N.Y. Civ. Prac. Act $\$ 306$.

29. Cal. Code Civ. P. ANN. §1871 (Deering, 1953).

- 30. Here again, the main emphasis has been on criminal cases. State v. Petty, 32 Nev. 384, 108 Pac. 934 (1910); State v. Horne, 171 N.C. 787, 88 S.E. 433 (1916). Sce also Schroeder v. C., R.I. \& P.R.R., 47 Iowa 375, 380 (1877) (reversal on appeal after defendant's motion to have plaintiff in a personal injury action submit to a physical examination was denied by the trial court): "The plaintiff, as it were, had under his own control testimony which would have revealed the truth more clearly than any other that could have been introduced. The cause of truth, the right administration of the law, dcmand that he should have produced it." Iowa at that time had no statute or court rule on the subject; it has subsequently adopted Federal Rule 35. See note 21 supra. 
apparently none of the states had a systematic project for civil cases, implemented with a readily available panel of experts.

However, the Workmen's Compensation Board of New York has for some years obtained impartial medical testimony in much the same way as the Project does. The Board employs a permanent staff of medical examiners. ${ }^{31}$ It is customary for the Board to require the parties to introduce the testimony of attending and examining physicians before cases are referred for opinion to Board medical consultants. ${ }^{32}$ The opinion of the impartial specialist is weighed by the Board with the testimony submitted by the parties. ${ }^{.3}$ There are also provisions enabling the Eoard to require on its own motion examination of a claimant by a physician especially qualified with respect to specific diseases. ${ }^{34}$ The similarities between the Board's provisions and those of the current Project suggest that the Project represents less of an innovation than a belated extension of tested procedures to the field of civil litigation. .35

But in one kind of personal injury case, the New York Project apparently operates under marked limitations. The Project provides that all of the reports of the doctors for both sides are to be submitted to the impartial physician prior to the examination. In cases likely to involve medical histories prior to the accident which is the subject of litigation, claimants sometimes withhold full disclosure of earlier treatment. ${ }^{30}$ This problem has arisen particularly in suits involving alleged injury to intervertebral dises, and cases

31. The Board employs medical examiners in approximately the ratio of one physician for each referee calendar. In urban centers the members of the medieal stafi exist as a separate entity, making their examinations in rotation without reference to the calendar from which the case emanates. Communication to the YALE LAw Joun:aAr from John G. Brigham, Assistant Secretary, Workmen's Compensation Board, State of New York, dated February 24, 1954, in Yale Law Library. The Board medieal examiners advise as to degree of disability, and staff doctors are not available to the parties as expert witnesses upon issues not submitted to them by the Board. Kosenfeld v. Ranger Plastics, 272 App. Div. 986, 72 N.I.S.2d SOS (3d Dep't 1947).

32. Communication from John G. Brigham, supra note 31 . The Board uses its medical staff a great deal. There were 163,910 claimants referred for medical examinations by Board doctors during 1952 . The Board entertained a total of 564,829 claims during that year. Annual Report, Workifen's Compensation Bonro, State of New Yonk 14,18 (1952).

33. Such opinion is in no sense conclusive. Mfoniot $v$. Empire State Wine Co, 282 App. Div. S99, 124 N.Y.S.2d 880 (3d Dep't 1953) ; Cross v. Wilson \& Co., 231 App. Div. 719, 117 N.Y.S.2d 760 (3d Dep't 1952) ; Kogan v. Schoen Printing Co., 276 App. Div. 935,94 N.Y.S.2d 257 (3d Dep't 1950).

34. A referee on recommendation of the Mfedical Director of the Board may require the same. N.Y. Worknien's Conpensation L.hy \$13(d). A special provision enables the Board to retain as consultants experts in silicosis and other dust diseases. Id. $\$ 49-\mathrm{a}$

35. Impartial medical boards have been features of Worlumen's Compensation procedure in other states as well as New York. See Yerion, Exfert Medical Testimony in: Compensation Proceedings, 2 Law and Contearp. Psob. 476 (1935).

36. Communication to the Yale Law Jounar from Harold Schafiner, Hartiord Accident \& Indemnity Co., dated March 12, 1954, in Yale Law Library. 
involving neurological or psychological complaints. ${ }^{37}$ Without a full picture of the plaintiff's prior history, it is difficult for the examining physician to determine just what symptoms are the result of the accident. No ready solution presents itself. The physician-patient privilege, broadly applied in New York, ${ }^{38}$ would interfere with any directive requiring the plaintiff to make full medical disclosure. But the impartial examiner's opinion should be of some value even without full disclosure, particularly at the pre-trial level. And in many cases this particular limitation is not a factor.

The advantages of the New York Project should be extended to other fields equally in need of its benefits. ${ }^{30}$ Limiting the Project's application to

37. Ibid.

38. N.Y. City Council v. Goldwater, 284 N.Y. 296, 31 N.E.2d 31 (1940); Kinbacher v. Schneider, 194 Misc. 969, 89 N.Y.S.2d 350 (Sup. Ct. 1949) ; N.Y. Crv. PuAc. Acr $\S \S 352,354$. The privilege is fully as effective in pre-trial examinations as it is at the trial. Kriebel v. Commercial T.M.A. Ass'n, 63 N.Y.S.2d 282 (Sup. Ct. 1946). Sec also 8 Wignore, Evidence $\$ \S 2380-91$ (3d ed. 1940). However, the proccedings at the impartial physician's examination would clearly not be privileged. Id. $\$ 2382$; Pcople v. Sliney, 137 N.Y. 570, 33 N.E. 150 (1893).

A doctrine of implied waiver of the privilege by bringing a suit involving the physical condition of the plaintiff has been advocated, 8 WIGMORE, EvIDENCE $\$ 2389$ (3d ed. 1940), but thus far has been shunned by the courts. New York's view is that waiver of the privilege may be accomplished only in open court on the trial, or by stipulation. Rubin v. Equitable Ass. Soc'y, 269 App. Div. 677, 53 N.Y.S.2d 351 (2d Dep't 1945).

Even if full disclosure of prior medical treatment could be achieved, there is a real question as to whether the panel physicians, all of them active in private practice, would have time to study and evaluate the material.

39. Achievements of the Project to date have been encouraging. "I have no doubt that this is a sound program and one that should be carried into the regular court procedure and budget. Perhaps we have found that there are fewer cases to refer to the panel than we might have anticipated. That means fewer cases about which there is a wide difference of medical opinion between the two sides. On the other hand, there are certainly many such cases and they are the toughest ones and the ones with the greatest uncertainty and lack of satisfaction or confidence in handling them in the usual way of a jury attempting to choose between two partisan experts. Whenever these cases can be disposed of without trial by aid of the independent medical panel, court time is saved. What is even more important, however, is that the disposition of the cases either with or without trial is upon a sounder and surer basis than if the independent panel were not available. The program thus contributes both to true and timely justice." Communication to the Yale Law Journal from David W. Peck, Presiding Justice, Supreme Court, New York State, Appellate Division, First Department, dated March 15, 1954, in Yale Law Library.

"We have encountered the New York Medical Expert Testimony Project on several occasions at the pre-trial level. Based upon our experience, it is our opinion that the Project is very helpful to all parties to the litigation and as time goes on it will be used more and its value will increase. It is also our opinion that its use saves considerable time in both pre-trial and the actual trial." Communication to the YALE LAW JouRNal from Frederic J. Locker, Galli \& Locker, counsel in the metropolitan area for Travelers Ins. Co., dated March 15, 1.954, in Yale Law Library.

But contrast the following opinion: "At the very outset, one must realize that medical opinions cannot be given with absolute mathematical certainty. . . . Despite the great 
"personal injury cases" seems unfortunate, particularly in view of the strict construction of this phrase that the New York courts have established." Adoption of Federal Rule 35's language-"in an action in which the mental or physical condition of a party is in controversy"-would enable medical expert testimony under the Project to be available in several areas currently not covered by the plan. Impartial medical testimony could be of utility not only in personal injury cases, but in malpractice litigation, suits on insurance policies, and similar disputes.

progress that medicine has made, the honest differences of orinion on medical matters are sometimes amazing. ... The great injustice where a Panel doctor is ealled as a witness for either side lies in the fact that he has been appointed by the Court. ... It is almost impossible to overcome in the minds of the jury the impression that the Panel doctor is a person who is strictly impartial. He is a species of Deus ex machina and Delphic Oracle. Thus, the opinion of any other doctor, if it conflicts with his, is generally disregarded." Communication from Isidore Halpern, supra note 12.

A full statistical report on the Project's experimental period will be made public in December, 1954.

40. Herskovitz v. Travelers Ins. Co., 272 App. Div. 5\&4, 73 N.Y.S.2d 851 (1st Dep't 1947) (action to recover disability payments on a life policy payable in event plaintifiinsured became wholly disabled by badily injuries or disease; order for physical examination reversed on grounds that this was not a "personal injury case"). 